\title{
KEPUASAN PENGGUNA TERHADAP LMS BINUSMAYA: PERSPEKTIF IMPLEMENTASI CRM PADA INSTITUSI PENDIDIKAN UNTUK KARAKTERISTIK LAYANAN
}

\author{
Meyliana; Henry Antonius E. W.; Stephen W. Santoso \\ Information Systems Department, School of Information Systems, Binus University \\ Jl. K.H. Syahdan No. 9, Palmerah, Jakarta Barat 11480 \\ meyliana@binus.edu; haew@binus.edu; ssantoso@binus.edu
}

\begin{abstract}
ABSTRAK
Konsep customer relationship telah berubah menjadi customer engagement, yang kini dikenal sebagai konsep Customer Relationship Management (CRM). Karakteristik CRM mengakomodir tiga hal: pemasaran, penjualan, dan layanan. Industri pendidikan memiliki karakteristik paling kuat pada layanan karena keterikatan pelanggan untuk waktu yang cukup lama pada institusi pendidikan. Kepuasan pelanggan akan memberikan rekomendasi positif kepada keluarga dan kerabatnya. Sebaliknya ketidakpuasan pelanggan akan membawa rekomendasi kurang baik. Dengan demikan, pelayanan pelanggan selama masih terikat dengan perusahaan sangat menentukan keberlangsungan bisnis perusahaan selanjutnya. Penelitian dilakukan menggunakan model EUCS (End User Computing System) dimana hipotesisnya diuji berdasarkan análisis korelasi dan análisis regresi serta menggunakan IPA (Importance Performance Analysis) untuk melihat hal-hal yang perlu ditingkatkan dengan menghitung gap analisisnya. Berdasarkan análisis korelasi, semua hipotesis H1 (ada hubungan) diterima dan berdasarkan análisis regresi, semua hipotesis H1 (berpengaruh) diterima. Dan berdasarkan IPA, tiga dari lima variabel perlu peningkatan sebagai prioritas pertama. Sementara untuk prioritas kedua semua variabel perlu ditingkatkan.
\end{abstract}

Kata kunci: CRM, layanan, LMS, kepuasan pengguna

\begin{abstract}
Customer relationship concept now has turned into customer engagement, known as Customer Relationship Management (CRM). The characteristics of CRM accommodate three things: marketing, sales, and services. Education industry has the most powerful characteristics of the service because the customers are bounded to the institution in longer time. Customer satisfaction will give positive recommendations to their families and relatives. In contrast, customer dissatisfaction will bring unfavorable recommendation. Thus, services for the customers who are still linked to the company will determine the company's business continuity. This study used EUCS (End User Computing System) model to determined the variable where the hypothesis was tested by correlation analysis and regression analysis. IPA (Importance performance Analysis) is used to to analyze what to be improved by calculating the gap analysis. Based on correlation analysis, all H1 hypothesis (have relationship) is accepted and based on regression analysis, all the hypotheses H1 (influencing) is accepted. Based on IPA, three of five variables are the first priority for improvement. All variables are the second priority to be improved.
\end{abstract}

Kata kunci: CRM, service, LMS, user satisfaction 


\section{PENDAHULUAN}

Perubahan konsep mendasar dari posisi pelanggan sangat mempengaruhi perkembangan bisnis suatu perusahaan. Saat ini pelanggan bukan lagi sebagai pihak luar dari suatu perusahaan, melainkan sudah masuk ke dalam perusahaan itu sendiri. Posisi pelanggan telah menjadi fokus strategi keberhasilan suatu perusahaan. Konsep inilah yang disebut dengan Customer Engagement, bukan hanya sekedar Customer Relationship (Greenberg, 2010).

Customer Engagement merupakan fokus dalam implementasi Customer Relationship Management (CRM). CRM memiliki tiga karakteristik utama yaitu pemasaran (marketing), penjualan (sales), dan layanan (service). Definisi CRM adalah filosofi dan strategi bisnis yang didukung oleh sistem dan teknologi yang didesain untuk meningkatkan interaksi manusia dalam lingkungan bisnis. Seiring semakin meluasnya penggunaan social media yang di dalamnya terdapat konsep social networking, konsep CRM pun mulai bergeser menjadi Social CRM. Definisi Social CRM adalah strategi bisnis yang didukung oleh teknologi, peraturan bisnis, proses, dan karakteristik sosial yang didesain untuk mengikutsertakan pelanggan dalam interaksi yang terkolaborasi untuk memberikan nilai yang saling menguntungkan dalam lingkungan bisnis yang jujur dan transparan sebagai respon perusahaan terhadap kepemilikan pelanggan atas interaksi tersebut (Greenberg, 2010).

CRM sering juga disebut dengan e-CRM karena menggunakan teknologi dalam implementasinya. Definisi e-CRM adalah penggunaan teknologi komunikasi digital untuk memaksimalkan penjualan kepada pelanggan dan memacu penggunaan jasa online yang berkelanjutan (Chaffey, 2009).

Penelitian ini dilakukan pada perusahaan jasa yaitu institusi pendidikan. Institusi pendidikan adalah perusahaan jasa yang memiliki karakteristik berbeda atau unik dibandingkan perusahaan jasa pada umumnya. Seorang pelanggan akan terikat untuk waktu yang relatif lama sehingga jika pelanggan merasa tidak puas maka ketidakpuasan itu akan menjadi terakumulasi karena pelanggan tidak dapat langsung pindah ke tempat lain. Akibat terakumulasinya ketidakpuasan ini membuat pelanggan akan memberikan rekomendasi yang negatif terhadap institusinya dan tidak akan merekomendasikan orang-orang yang dekat dan dikenalnya untuk masuk ke institusi tersebut. Sebaliknya jika pelanggan merasa terpuaskan maka hal ini akan tercermin dari rekomendasi yang diberikannya. Keterikatan pelanggan yang relatif lama pada institusi pendidikan menuntut perusahaan harus sangat memperhatikan layanan (service) kepada pelanggannya. Dengan memberikan layanan (service) yang berkualitas, perusahaan akan mampu mempertahankan pelanggannya dan juga akan mendapatkan rekomendasi yang positif untuk mendapatkan pelanggan baru.

Institusi pendidikan yang dipilih dalam penelitian ini adalah BINUS University dan layanan (service) yang akan dibahas adalah BINUSMaya (binusmaya.binus.ac.id), suatu sistem pengelolaan pembelajaran yang sering disebut dengan LMS (Learning Management System). BINUSMaya menggabungkan konten pembelajaran dengan informasi yang bersifat services. Tujuan penelitian ini untuk mengetahui seberapa baik kualitas BINUSMaya yang dimiliki BINUS University sebagai salah satu perspektif penerapan CRM untuk karakteristik layanan (service) menurut pendapat penggunanya. Sedangkan manfaat yang didapat dengan penelitian ini adalah memberikan informasi mengenai hubungan BINUSMaya dengan kepuasan penggunanya dan memberikan rekomendasi yang dibutuhkan untuk peningkatan kualitas BINUSMaya menurut pendapat penggunanya.

Perumusan masalahnya adalah apakah kepuasan pengguna dalam menggunakan BINUSMaya memiliki hubungan dan dampak yang signifikan dengan satisfaction \& loyalty, dan hal-hal apa saja yang harus dikembangkan dalam BINUSMaya agar dapat lebih meningkatkan kepuasan pengguna yang berdampak pada peningkatan daya saing perusahaan. 
Hipotesis disusun berdasarkan analisis korelasi dan analisis regresi berganda menjadi 10 hipotesis, yaitu:

Hipotesis 1:

H0: Content tidak berhubungan dengan Satisfaction \& Loyalty.

H1: Content berhubungan dengan Satisfaction \& Loyalty.

Hipotesis 2:

H0: Accuracy tidak berhubungan dengan Satisfaction \& Loyalty.

H1: Accuracy berhubungan dengan Satisfaction \& Loyalty.

Hipotesis 3:

H0: Format tidak berhubungan dengan Satisfaction \& Loyalty.

H1: Format berhubungan dengan Satisfaction \& Loyalty.

Hipotesis 4:

H0: Ease of Use tidak berhubungan dengan Satisfaction \& Loyalty.

H1: Ease of Use berhubungan dengan Satisfaction \& Loyalty.

Hipotesis 5:

H0: Timeliness tidak berhubungan dengan Satisfaction \& Loyalty.

H1: Timeliness berhubungan dengan Satisfaction \& Loyalty.

Hipotesis 6:

H0: Content tidak memiliki pengaruh terhadap Satisfaction \& Loyalty.

H1: Content memiliki pengaruh terhadap Satisfaction \& Loyalty.

Hipotesis 7:

H0: Accuracy tidak memiliki pengaruh terhadap Satisfaction \& Loyalty.

H1: Accuracy memiliki pengaruh terhadap Satisfaction \& Loyalty.

Hipotesis 8:

H0: Format tidak memiliki pengaruh terhadap Satisfaction \& Loyalty.

H1: Format memiliki pengaruh terhadap Satisfaction \& Loyalty.

Hipotesis 9:

H0: Ease of Use tidak memiliki pengaruh terhadap Satisfaction \& Loyalty.

H1: Ease of Use memiliki pengaruh terhadap Satisfaction \& Loyalty.

Hipotesis 10:

H0: Timeliness tidak memiliki pengaruh terhadap Satisfaction \& Loyalty.

H1: Timeliness memiliki pengaruh terhadap Satisfaction \& Loyalty.

\section{METODE}

Metodologi penelitian yang digunakan dapat dilihat pada Gambar 1 berikut.

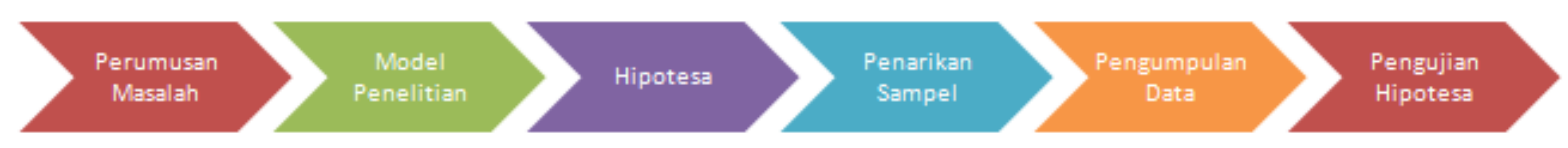

Gambar 1. Metodologi penelitian. 
Model penelitian di atas menggunakan model EUCS (End User Computing Satisfaction) menurut Doll \& Torkzadeh (Gambar 2). Model EUCS menyatakan bahwa kepuasan user terhadap suatu web dapat ditentukan melalui beberapa variabel, yakni: Content, Accuracy, Format, Ease to Use, Timeliness (Doll \& Torkzadeh, 1988). Variabel EUCS akan menjadi variabel bebas dan variabel terikatnya adalah satisfaction \& loyalty.

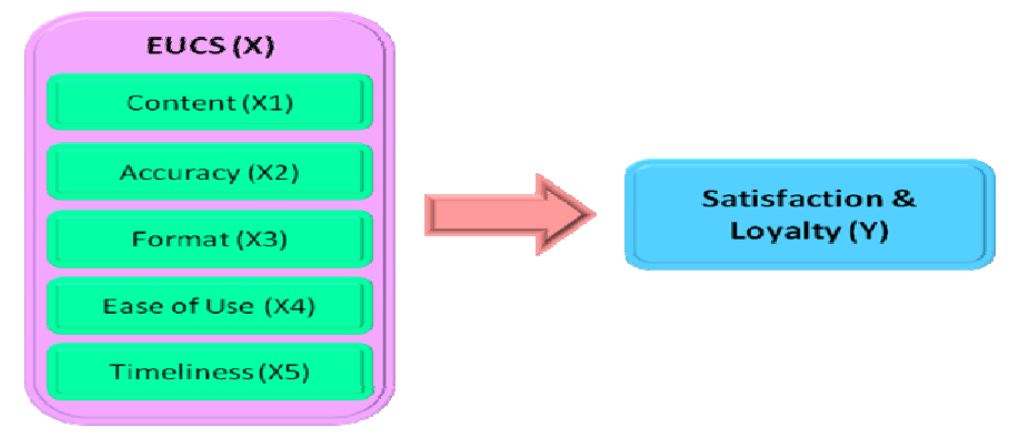

Gambar 2. Model penelitian.

\section{Keterangan variable:}

Content (X1): Variabel ini untuk mengukur ketersediaan informasi yang tepat, benar dan konsisten, yang sesuai kebutuhan pengguna, dan memiliki fitur-fitur yang lengkap.

Accuracy (X2): Variabel ini mengukur keakuratan informasi yang dihasilkan, memiliki integritas keutuhan data, menghasilkan formula/rumus yang tepat, mengembalikan hasil pencarian yang tepat, dan memberikan informasi sesuai hak akses pengguna.

Format (X3): Variabel ini mengukur apakah desain situs menarik bagi pengguna (memiliki tampilan yang menarik, panduan warna yang serasi, tata letak yang rapi, dan memiliki standarisasi/keseragaman format).

Ease of Use (X4): Variabel ini mengukur kemudahan penggunaan situs bagi penggunanya (user friendly, mudah digunakan, memberikan pesan kesalahan yang informatif, memiliki cara penggunaan yang konsisten, menyediakan tool tip sebagai informasi tambahan, dan memiliki fitur panduan pengguna.

Timeliness (X5): Variabel ini mengukur kecepatan dan keterbaruan informasi (memberikan response time yang cepat, informasi yang selalu ter-uptodate, memiliki shortcut untuk mempercepat perpindahan menu).

Satisfaction \& Loyalty (Y): Variabel ini mengukur kepuasan pengguna (mahasiswa) terhadap kinerja BINUSMaya, loyalitas mahasiswa terhadap institusi dan keinginan mahasiswa memberikan rekomendasi institusi kepada orang lain.

Analisis korelasi dilakukan untuk melihat apakah ada hubungan antara varibel bebas dan variabel terikat dan korelasi ini dilakukan menggunakan teknik korelasi Product Moment, yang rumusnya data dijelaskan sebagai berikut (Sugiyono, 2008).

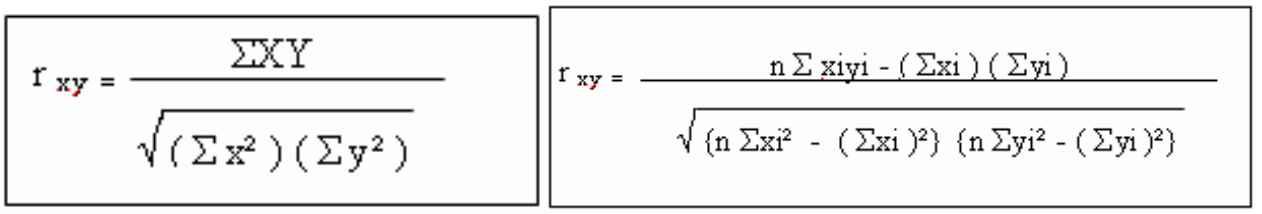




\section{Keterangan:}

$R=$ Koefisien korelasi

$x i=$ Jumlah variabel $X$

$y i=$ Jumlah variabel $Y$

$n=$ Jumlah Sampel

Sedangkan analisis regresi berganda dilakukan untuk menguji apakah variabel bebas memiki pengaruh atau dampak terhadap variabel terikat dan berapa besar pengaruh tersebut. Bentuk persamaan regresi: $Y^{\prime}=a+b X$, dimana

$Y^{\prime}=$ subyek dalam variabel dependen yang diprediksikan

$a=$ harga $\mathrm{Y}$ bila $\mathrm{X}=0$ (harga konstan)

$b=$ angka arah atau koefisien regresi, yang menunjukkan angka

$X=$ subyek pada variabel independen yang mempunyai nilai tertentu.

Peningkatan ataupun penurunan variabel terikat yang didasarkan pada variabel bebas. Bila b ( +), naik; bila ( - ), terjadi penurunan (Sugiyono, 2008).

Untuk melihat hal-hal yang harus ditingkatkan pada BINUSMaya, akan digunakan gap analisis dengan menggunakan metode IPA (Importance Performance Analysis). Metode IPA pertama kali diperkenalkan oleh Martilla dan James pada tahun 1977 dengan tujuan untuk mengukur hubungan antara persepsi konsumen dan prioritas peningkatan kualitas produk/ jasa yang dikenal pula sebagai quadrant analysis (Brandt, 2000 dan Latu \& Everett, 2000). IPA telah diterima secara umum dan dipergunakan pada berbagai bidang kajian karena kemudahan untuk diterapkan dan tampilan hasil analisis yang memudahkan usulan perbaikan kinerja (Martinez, 2003). IPA mempunyai fungsi utama untuk menampilkan informasi berkaitan dengan faktor-faktor pelayanan yang menurut konsumen sangat mempengaruhi kepuasan dan loyalitas mereka, dan faktor-faktor pelayanan yang menurut konsumen perlu ditingkatkan karena kondisi saat ini belum memuaskan.

IPA menggabungkan pengukuran faktor tingkat kepentingan dan tingkat kepuasan dalam grafik dua dimensi yang memudahkan penjelasan data dan mendapatkan usulan praktis. Interpretasi grafik IPA sangat mudah, dimana grafik IPA dibagi menjadi empat buah kuadran berdasarkan hasil pengukuran sebagaimana terlihat pada Gambar 3.

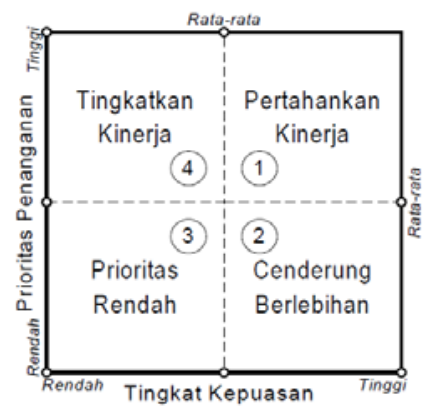

Gambar 3. Pembagian kuadran Importance Performance Analysis.

Berikut penjelasan untuk masing-masing kuadran (Brandt, 2000). Kuadran Pertama, 'Pertahankan Kinerja' (high importance \& high performance). Faktor-faktor yang terletak pada kuadran ini dianggap sebagai faktor penunjang bagi kepuasan konsumen sehingga pihak manajemen berkewajiban memastikan bahwa kinerja institusi yang dikelolanya dapat terus mempertahankan prestasi yang telah dicapai. 
Kuadran Kedua, 'Cenderung Berlebihan' (low importance \& high performance). Faktor-faktor yang terletak pada kuadran ini dianggap tidak terlalu penting sehingga pihak manajemen perlu mengalokasikan sumber daya yang terkait dengan faktor-faktor tersebut kepada faktor-faktor lain yang mempunyai prioritas penanganan lebih tinggi yang masih membutuhkan peningkatan, semisal dikuadran keempat.

Kuadran Ketiga, 'Prioritas Rendah' (low importance \& low performance). Faktor-faktor yang terletak pada kuadran ini mempunyai tingkat kepuasan yang rendah dan sekaligus dianggap tidak terlalu penting bagi konsumen, sehingga pihak manajemen tidak perlu memprioritaskan atau terlalu memberikan perhatian pada faktor -faktor tersebut.

Kuadran Keempat, 'Tingkatkan Kinerja' (high importance \& low performance). Faktor-faktor yang terletak pada kuadran ini dianggap sebagai faktor yang sangat penting oleh konsumen namun kondisi pada saat ini belum memuaskan sehingga pihak manajemen berkewajiban mengalokasikan sumber daya yang memadai untuk meningkatkan kinerja berbagai faktor tersebut. Faktor-faktor yang terletak pada kuadran ini merupakan prioritas untuk ditingkatkan.

Ada dua macam metode untuk menampilkan data IPA, yaitu: pertama, menempatkan garis perpotongan kuadran pada nilai rata-rata pada sumbu tingkat kepuasan dan sumbu prioritas penangganan dengan tujuan untuk mengetahui secara umum penyebaran data terletak pada kuadran berapa. Pada bagian ini digunakan nilai rata-rata pada skala pengukuran tingkat kepuasan dan prioritas penanganan sebagai garis pemisah antar kuadran. Kedua, menempatkan garis perpotongan kuadran pada nilai rata-rata hasil pengamatan pada sumbu tingkat kepuasan dan sumbu prioritas penangganan dengan tujuan untuk mengetahui secara spesifik masing-masing faktor terletak pada kuadran berapa. Pada bagian ini digunakan nilai rata-rata hasil pengukuran tingkat kepuasan dan prioritas penanganan sebagai garis pemisah antar kuadran (Martinez, 2003). Berikut prosedur berkaitan dengan penggunaan metode IPA: (1) penentuan faktor-faktor yang akan dianalisis; (2) melakukan survey melalui penyebaran kuesioner; (3) menghitung nilai rata-rata tingkat kepuasan dan prioritas penanganan; (4) membuat grafik IPA; (5) melakukan evaluasi terhadap faktor sesuai dengan kuadran masing-masing.

\section{HASIL DAN PEMBAHASAN}

Metode transformasi yang digunakan yaitu method of successive interval (Hays, 1976). Metode tersebut digunakan untuk melakukan transformasi data ordinal menjadi data interval. Pada umumnya jawaban responden yang diukur dengan menggunakan skala likert (Lykert scale) diadakan scoring, yaitu pemberian nilai numerikal $1,2,3,4$, dan 5 . Setiap skor yang diperoleh akan memiliki tingkat pengukuran ordinal. Nilai numerikal tersebut dianggap sebagai objek dan selanjutnya melalui proses transformasi ditempatkan ke dalam interval. Langkah-langkahnya adalah sebagai berikut: (1) untuk setiap pertanyaan, hitung frekuensi jawaban setiap kategori (pilihan jawaban); (2) berdasarkan frekuensi setiap kategori dihitung proporsinya; (3) dari proporsi yang diperoleh, hitung proporsi kumulatif untuk setiap kategori; (4) tentukan pula nilai batas Z untuk setiap kategori; (5) hitung scale value (interval rata-rata) untuk setiap kategori melalui persamaan berikut:

$$
\text { Seale }=\frac{\text { Kepadatan batas bawah }- \text { Kepadatan batas atas }}{\text { daerah dt bawah batag atas - daerah di bawah batas bawah }}
$$

(6) hitung score (nilai hasil transformasi) untuk setiap kategori melalui persamaan: score $=$ scaleValue $+\mid$ scaleValuemin $\mid+1$ 
Populasi dalam penelitian ini adalah semua mahasiswa aktif jurusan Sistem Informasi BINUS University yaitu BINUSIAN 2011, 2012, 2013, dan 2014 yang berjumlah 4.467 mahasiswa. Jumlah detilnya dapat dilihat pada Tabel 2.

Tabel 2

Jumlah Mahasiswa Aktif Jurusan Sistem Informasi

\begin{tabular}{cc}
\hline BINUSIAN & Jumlah Mahasiswa Aktif \\
\hline 2011 & 989 \\
\hline 2012 & 1.137 \\
\hline 2013 & 1.112 \\
\hline 2014 & 1.229 \\
\hline Total & $\mathbf{4 . 4 6 7}$ \\
\hline
\end{tabular}

Untuk menghitung jumlah sampel dari populasi tersebut digunakan rumus Isaac dan Michael. Dari tabel perhitungan sampel (Sugiyono, 2008) didapatkan bahwa apabila jumlah populasi 4467 mahasiswa, jumlah sampelnya adalah 323 mahasiswa. Dengan taraf kesalahan 5\% didapat hasil jumlah kuesioner yang harus dikumpulkan disesuaikan dengan jumlah populasi masing-masing angkatan (Tabel 3).

Tabel 3

Responden Kuesioner Valid

\begin{tabular}{cccc}
\hline Responden & Jumlah Responden & Kuesioner yang Disebarkan & Kuesioner yang Terkumpul \\
\hline Binusian 2011 & 989 & 120 & 120 \\
\hline Binusian 2012 & 1.137 & 100 & 97 \\
\hline Binusian 2013 & 1.112 & 70 & 35 \\
\hline Binusian 2014 & 1.229 & 100 & 74 \\
\hline Total & $\mathbf{4 . 4 6 7}$ & $\mathbf{3 9 0}$ & $\mathbf{3 2 6}$ \\
\hline
\end{tabular}

Teknik pengumpulan data yaitu melakukan studi lapangan secara langsung dan sampling membagikan kuesioner kepada pengguna situs BINUSMaya. Data yang terkumpul diukur menggunakan statistical analysis tools seperti software SPSS 17.0 atau Microsoft Excel dan metode yang digunakan ialah multiple regression dan correlation model.

Kuesioner yang disebaran kepada responden berisikan pertanyaan-pertanyaan yang berkaitan dengan variabel EUCS (X) dan variabel Satisfaction \& Loyalty (Y). Berikut daftar dari pertanyaan yang diajukan melalui kuesioner kepuasan pengguna terhadap BINUSMaya (Meyliana, Ihandi, Sukanto, Willyanta, 2011), yang dapat dilihat pada Tabel 4 berikut ini.

Secara sederhana uji validitas dan reliabilitas dilakukan dengan membandingkan nilai korelasi ( $\mathrm{r}$ hitung) dan Cronbach's Alpha yang dihasilkan dengan menggunakan bantuan software SPSS Statistic 17.0, dengan nilai dari $r$ tabel. Secara umum, ketentuannya adalah jika nilai korelasi ( $\mathrm{r}$ hitung) lebih besar dari $r$ tabel, pertanyaan tersebut dikatakan valid. Demikian juga jika Cronbach's Alpha lebih besar daripada $r$ tabel, variabel tersebut dapat dipercaya. Dikarenakan banyaknya pertanyaan dan jumlah variabel yang diuji serta melibatkan dua sudut pandang penilaian sekaligus (derajat kepentingan dan kenyaataan), skenario pengujian validitas dan reliabilitas dibagi ke dalam empat bagian, yaitu: uji validitas untuk derajat kepentingan, uji validitas untuk derajat kepuasan, uji reliabilitas untuk derajat kepentingan, dan uji reliabilitas untuk derajat kepuasan. Untuk n sebanyak 30 dan $\alpha 5 \%$, nilai $r$ tabel adalah 0,361 . 
Tabel 4

Daftar Variabel dan Pertanyaan

\begin{tabular}{|c|c|}
\hline \multicolumn{2}{|r|}{ Content (X1) } \\
\hline $\mathrm{X} 1.1$ & Situs menyediakan informasi yang tepat dan benar \\
\hline $\mathrm{X} 1.2$ & Situs menyediakan informasi yang sesuai dengan kebutuhan mahasiswa \\
\hline $\mathrm{X} 1.3$ & Situs menyediakan fitur-fitur yang mendukung proses pembelajaran secara lengkap \\
\hline $\mathrm{X} 1.4$ & Situs mempunyai konsistensi / keseragaman informasi \\
\hline \multicolumn{2}{|r|}{ Accuracy (X2) } \\
\hline $\mathrm{X} 2.1$ & Situs menyediakan informasi yang akurat \\
\hline $\mathrm{X} 2.2$ & Situs mempunyai integritas keutuhan data \\
\hline $\mathrm{X} 2.3$ & Situs menghasilkan perhitungan formula atau rumus yang tepat \\
\hline $\mathrm{X} 2.4$ & Situs dapat mengembalikan hasil pencarian yang tepat \\
\hline $\mathrm{X} 2.5$ & Situs dapat memberikan informasi yang sesuai dengan hak akses user \\
\hline \multicolumn{2}{|r|}{ Format (X3) } \\
\hline $\mathrm{X} 3.1$ & Situs mempunyai tampilan yang menarik \\
\hline $\mathrm{X} 3.2$ & Situs mempunyai panduan warna yang serasi \\
\hline $\mathrm{X} 3.3$ & Situs mempunyai tata letak yang rapi \\
\hline $\mathrm{X} 3.4$ & Situs mempunyai standarisasi atau keseragaman format \\
\hline \multicolumn{2}{|r|}{ Ease of Use (X4) } \\
\hline $\mathrm{X} 4.1$ & Situs sangat user friendly \\
\hline $\mathrm{X} 4.2$ & Situs sangat mudah digunakan \\
\hline $\mathrm{X} 4.3$ & Situs memberikan pesan kesalahan yang informatif \\
\hline $\mathrm{X} 4.4$ & Situs mempunyai cara penggunaan yang konsisten \\
\hline $\mathrm{X} 4.5$ & Situs menyediakan tool tip sebagai informasi tambahan \\
\hline $\mathrm{X} 4.6$ & Situs memiliki fitur panduan pengguna \\
\hline \multicolumn{2}{|r|}{ Timeliness (X5) } \\
\hline $\mathrm{X} 5.1$ & Situs memberikan response time yang cepat \\
\hline $\mathrm{X} 5.2$ & Situs menyediakan informasi yang ter up-to-date \\
\hline $\mathrm{X} 5.3$ & Situs memiliki shortcut untuk mempercepat perpindahan menu \\
\hline \multicolumn{2}{|r|}{ Satisfaction \& Loyalty (Y) } \\
\hline Y1 & Kepuasan mahasiswa dengan kinerja BINUSMaya \\
\hline Y2 & Loyalitas mahasiswa terhadap BINUS University \\
\hline Y3 & Keinginan mahasiswa untuk merekomendasikan BINUS University \\
\hline
\end{tabular}

Tabel 5

Hasil Uji Validitas dan Reliabilitas

\begin{tabular}{|l|l|c|l|c|}
\hline \multirow{2}{*}{ Validitas } & \multicolumn{2}{|c|}{ Kepentingan } & \multicolumn{2}{c|}{ Kepuasan } \\
\hline \multirow{2}{*}{ Variabel } & \multicolumn{2}{|c|}{ Valid } & Tidak Valid & \multicolumn{2}{c|}{ Valid } & Tidak Valid \\
\cline { 2 - 5 } & \multicolumn{1}{|c|}{} & - & $\mathrm{X} 1.1, \mathrm{X} 1.2, \mathrm{X} 1.3, \mathrm{X} 1.4$ & - \\
\hline Content (X1) & $\mathrm{X} 1.1, \mathrm{X} 1.2, \mathrm{X} 1.3, \mathrm{X} 1.4$ & - & $\mathrm{X} 2.1, \mathrm{X} 2.2, \mathrm{X} 2.3, \mathrm{X} 2.4, \mathrm{X} 2.5$ & - \\
\hline Accuracy (X2) & $\mathrm{X} 2.1, \mathrm{X} 2.2, \mathrm{X} 2.3, \mathrm{X} 2.4, \mathrm{X} 2.5$ & - & $\mathrm{X} 3.1, \mathrm{X} 3.2, \mathrm{X} 3.3, \mathrm{X} 3.4$ & - \\
\hline Format (X3) & $\mathrm{X} 3.1, \mathrm{X} 3.2, \mathrm{X} 3.3, \mathrm{X} 3.4$ & - & $\mathrm{X} 4.1, \mathrm{X} 4.2, \mathrm{X} 4.3, \mathrm{X} 4.4, \mathrm{X} 4.5, \mathrm{X} 4.6$ & - \\
\hline Ease of Use (X4) & $\mathrm{X} 4.1, \mathrm{X} 4.2, \mathrm{X} 4.3, \mathrm{X} 4.4, \mathrm{X} 4.5, \mathrm{X} 4.6$ & - & $\mathrm{X} 5.1, \mathrm{X} 5.2, \mathrm{X} 5.3$ & - \\
\hline Timeliness (X5) & $\mathrm{X} 5.1, \mathrm{X} 5.2, \mathrm{X} 5.3$ & - & $\mathrm{Y} 1, \mathrm{Y} 2, \mathrm{Y} 3$ & - \\
\hline Satisfaction \& Loyalty (Y) & $\mathrm{Y} 1, \mathrm{Y} 2, \mathrm{Y} 3$ & & \\
\hline
\end{tabular}

Reliabilitas
\begin{tabular}{|l|c|c|c|c|}
\hline \multirow{4}{*}{\multicolumn{1}{|c|}{ Variabel }} & \multicolumn{2}{|c|}{} \\
\cline { 2 - 5 } & Kepentingan & \multicolumn{2}{|c|}{ Kepuasan } \\
\cline { 2 - 5 } & Reliabel & $\begin{array}{c}\text { Tidak } \\
\text { Reliabel }\end{array}$ & Reliabel & $\begin{array}{c}\text { Tidak } \\
\text { Reliabel }\end{array}$ \\
\hline Content (X1) & v & - & v & - \\
\hline Accuracy (X2) & v & - & v & - \\
\hline Format (X3) & v & - & v & - \\
\hline Ease of Use (X4) & v & - & v & - \\
\hline Timeliness (X5) & v & - & v & - \\
\hline Satisfaction \& Loyalty (Y) & v & - & v & - \\
\hline
\end{tabular}

Dari hasil uji korelasi dengan metode Pearson, semua nilai korelasi ( $r$ hitung atau Pearson's Correlation) lebih besar dari $r$ tabel (0.098) dan nilai dari Sig (2-tailed) di bawah 0.05. sehingga H0 ditolak dan $\mathrm{H} 1$ diterima untuk hipotesis 1, 2, 3, 4 dan 5 (Tabel 6).

Dari hasil pengujian regresi didapat bahwa $R$ lebih besar dari ( $r$ tabel: 0.098) dan menunjukkan angka positif serta nilai Sig 0.000 (lebih kecil dari 0.05) sehingga H0 ditolak dan H1 diterima. Besarnya dampak/pengaruh variabel $\mathrm{X}$ terhadap variabel $\mathrm{Y}$ dapat dilihat pada kolom Besar Pengaruh (dalam \%) dan data detilnya dapat dilihat pada Tabel 7. 
Tabel 6

Hasil Uji Korelasi

\begin{tabular}{|l|c|c|c|}
\hline \multicolumn{1}{|c|}{ Hipotesa } & $\begin{array}{c}\text { Pearson's } \\
\text { Correlation }\end{array}$ & Tidak ada hubungan $\left(\mathrm{H}_{0}\right)$ & Ada hubungan $\left(\mathrm{H}_{1}\right)$ \\
\hline Hipotesa 1 & 0,643 & Ditolak & Diterima \\
\hline Hipotesa 2 & 0,510 & Ditolak & Diterima \\
\hline Hipotesa 3 & 0,325 & Ditolak & Diterima \\
\hline Hipotesa 4 & 0,332 & Ditolak & Diterima \\
\hline Hipotesa 5 & 0,758 & Ditolak & Diterima \\
\hline
\end{tabular}

Tabel 7

Hasil Uji Regresi

\begin{tabular}{|l|c|c|c|c|c|}
\hline \multicolumn{1}{|c|}{ Hipotesa } & $\mathrm{R}$ & R Square & $\begin{array}{c}\text { Besar } \\
\text { Pengaruh }\end{array}$ & Tidak berpengaruh $\left(\mathrm{H}_{0}\right)$ & Berpengaruh $\left(\mathrm{H}_{1}\right)$ \\
\hline Hipotesa 6 & 0,683 & 0,467 & $46,7 \%$ & Ditolak & Diterima \\
\hline Hipotesa 7 & 0,776 & 0,602 & $60,2 \%$ & Ditolak & Diterima \\
\hline Hipotesa 8 & 0,656 & 0,430 & $43,0 \%$ & Ditolak & Diterima \\
\hline Hipotesa 9 & 0,672 & 0,451 & $45,1 \%$ & Ditolak & Diterima \\
\hline Hipotesa 10 & 0,880 & 0,774 & $77,4 \%$ & Ditolak & Diterima \\
\hline
\end{tabular}

Variabel yang harus menjadi perhatian adalah variabel yang berada di kuadran 2 karena kepentingannya tinggi, tapi kepuasannya rendah. Variabel yang berada di kuadran 2 akan masuk dalam perbaikan prioritas 1 dan variabel yang masuk dalam kuadran 3 akan masuk dalam perbaikan prioritas 2 (Tabel 8 dan 9).

Tabel 8

Hasil Gap Analisis

\begin{tabular}{|c|c|c|c|c|c|c|c|}
\hline \multirow{2}{*}{ Variabel } & \multicolumn{2}{|c|}{ Rata-rata } & \multirow{2}{*}{$\begin{array}{c}\text { Gap } \\
(\mathrm{Y}-\mathrm{X})\end{array}$} & \multicolumn{4}{|c|}{ Kuadran } \\
\hline & Kepentingan (X) & Kepuasan (Y) & & 1 & 2 & 3 & 4 \\
\hline Content (X1) & 3.59730 & 2.90093 & -0.69637 & $\mathrm{X} 1.1$ & $\mathrm{X} 1.3$ & $\mathrm{X} 1.2$ & $\mathrm{X} 1.4$ \\
\hline Accuracy (X2) & 3.32191 & 3.43636 & 0.11445 & $\mathrm{X} 2.3, \mathrm{X} 2.5$ & & $\mathrm{X} 2.2, \mathrm{X} 2.4$ & $\mathrm{X} 2.1$ \\
\hline Format (X3) & 3.55676 & 3.77798 & 0.22122 & X3.2 & X3.4 & X3.3 & $\begin{array}{l}\mathrm{X} 3.1 \\
\end{array}$ \\
\hline Ease of Use (X4) & 3.93194 & 3.812717 & -0.11922 & $\mathrm{X} 4.1$ & X4.4, X4.6 & $\mathrm{X} 4.3$ & $\mathrm{X} 4.2, \mathrm{X} 4.5$ \\
\hline Timeliness (X5) & 3.851343 & 3.51194 & -0.33940 & $\mathrm{X} 5.1$ & & $\mathrm{X} 5.3$ & $\mathrm{X} 5.2$ \\
\hline
\end{tabular}

Tabel 9

Rangkuman Prioritas Perbaikan

\begin{tabular}{|c|c|c|c|}
\hline Variabel & Faktor-faktor yang sudah optimal & $\begin{array}{c}\text { Faktor-faktor yang segera ditingkatkan } \\
\text { pada prioritas } 1\end{array}$ & $\begin{array}{l}\text { Faktor-faktor yang segera ditingkatkan pada } \\
\text { prioritas } 2 \\
\end{array}$ \\
\hline \multirow{2}{*}{ Content (X1) } & Situs menyediakan informasi yang tepat dan benar & \multirow{2}{*}{\begin{tabular}{|l|}
$\begin{array}{l}\text { Situs menyediakan fitur-fitur yang } \\
\text { mendukung proses pembelajaran }\end{array}$ \\
\end{tabular}} & \multirow{2}{*}{$\begin{array}{l}\text { Situs menyediakan informasi yang sesuai } \\
\text { dengan kebutuhan mahasiswa }\end{array}$} \\
\hline & Situs mempunyai konsistensi/ keseragaman informasi & & \\
\hline \multirow{3}{*}{ Accuracy (X2) } & Situs menghasilkan perhitungan formula atau rumus yang tepat & & Situs mempunyai integritas keutuhan data \\
\hline & Situs dapat memberikan informasi yang sesuai dengan hak akses user & & \multirow{2}{*}{$\begin{array}{l}\begin{array}{l}\text { Situs dapat mengembalikan hasil pencarian } \\
\text { yang tepat }\end{array} \\
\end{array}$} \\
\hline & Situs menyediakan informasi yang akurat & & \\
\hline \multirow{2}{*}{ Format (X3) } & Situs mempunyai panduan warna yang serasi & \multirow{2}{*}{$\begin{array}{l}\text { Situs mempunyai standarisasi atau } \\
\text { keseragaman format }\end{array}$} & \multirow{2}{*}{ Situs mempunyai tata letak yang rapi } \\
\hline & Situs mempunyai tampilan yang menarik & & \\
\hline \multirow{3}{*}{ Ease of Use (X4) } & Situs sangat user friendly & Situs mempunyai cara penggunaan & \multirow{3}{*}{$\begin{array}{l}\text { Situs memberikan pesan kesalahan yang } \\
\text { informatif }\end{array}$} \\
\hline & Situs sangat mudah digunakan & yang konsisten & \\
\hline & Situs menyediakan tool tip sebagai informasi tambahan & Situs memiliki fitur panduan pengguna & \\
\hline \multirow{2}{*}{ Timeliness (X5) } & Situs memberikan response time yang cepat & & \multirow{2}{*}{$\begin{array}{l}\text { Situs memiliki shortcut untuk mempercepat } \\
\text { perpindahan menu }\end{array}$} \\
\hline & Situs menyediakan informasi yang ter up-to-date & & \\
\hline
\end{tabular}




\section{PENUTUP}

Berdasarkan hasil pembahasan, dapat disimpulkan sebagai berikut: (1) dari hasil pengujian analisis korelasi dan regresi, dapat disimpulkan bahwa terdapat hubungan yang positif dan kuat antara Content, Accuracy, Format, Ease of Use, Timeliness, dan Satisfaction \& Loyalty; (2) dari hasil analisis korelasi didapat seluruh nilai $r$ variabel lebih besar dari $r$ tabel (0.098), sehingga semua hipotesis 1 $\left(\mathrm{H}_{1}\right)$ diterima dan hipotesis nol $\left(\mathrm{H}_{0}\right)$ ditolak; (3) dari analisis regresi didapat, semua hipotesis $1\left(\mathrm{H}_{1}\right)$ diterima dan hipotesis $0\left(\mathrm{H}_{0}\right)$ ditolak; (4) dari gap analisis, diketahui masih ada variabel yang perlu ditingkatkan pada prioritas 1 dan prioritas 2 . Adapun rekomendasi yang diusulkan kepada BINUS University untuk prioritas pertama adalah: (1) situs menyediakan fitur-fitur yang mendukung proses pembelajaran dengan lengkap, efisien, misalnya forum diskusi yang efisien dan e-mail untuk mahasiswa Binus University; (2) situs mempunyai standarisasi atau keseragaman format, contohnya dengan user interface yang sederhana dan mudah dimengerti; (3) situs mempunyai cara penggunaan yang konsisten, contohnya mendesain suatu web dengan konsistensi dan berkesinambungan antara satu halaman dengan halaman lainnya; (4) situs memiliki fitur panduan pengguna, dengan adannya petunjuk dan panduan dalam suatu web, maka dapat memberikan kemudahan bagi user dalam mengakses sebuah situs, misalnya dengan adannya fasilitas Help.

Sedangkan untuk prioritas kedua adalah: (1) situs menyediakan informasi yang sesuai dengan kebutuhan mahasiswa sehingga informasi tersebut dapat digunakan mahasiswa untuk mendukung proses perkuliahan mereka, misalnya dengan adanya bulletin dan private message; (2) situs mempunyai integritas keutuhan data. Sebuah situs harus memiliki database yang dapat menjaga integritas keutuhan data sehingga bila terjadi sesuatu data tetap dapat diakses; (3) situs harus dapat mengembalikan hasil pencarian yang tepat, karena seringkali sebuah situs tidak menampilkan hasil pencarian sesuai keinginan user-nya; (4) situs mempunyai tata letak yang rapi, dengan tata letak yang rapi tidak membingungkan user yang baru pertama kali mengakses website tersebut, misalnya dengan pembuatan form yang sederhana; (5) situs memberikan pesan kesalahan yang informatif, seringkali pesan kesalahan tidak menjawab apa pertanyaan dari user dan membuat user bingung mengapa terjadi error pada saat mengakses web tersebut; (6) situs memiliki shortcut untuk mempercepat perpindahan menu, misalnya shortcut untuk navigasi dari halaman satu ke halaman lainnya.

\section{DAFTAR PUSTAKA}

Brandt, D. R. (2000). An 'Outside-In' Approach to Determining Customer-Driven Priorities for Improvement and Innovation. White Paper Series, 2.

Chaffey, Dafe. (2009). E-Business and E-Commerce Management, (4 ${ }^{\text {th }}$ ed.). New York: Prentice Hall.

Doll, W. J., and G. Torkzadeh. (1988). Developing a Multidimensional Measure of System-use in an Organizational Context. Information \& Management, 33, 171-185.

Greenberg, Paul. (2010). CRM Customer Relationship Management, Social CRM Strategies, Tools, and Techniques for Engaging Your Customers, at the Speed of Light, (4th ed.). New York: McGraw-Hill.

Hays, W. L. (1976). Quantification in Psychology. New Delhi: Prentice Hall.

Latu, T. M., \& Everett, A. M. (2000). Review of Satisfaction Research and Measurement Approaches. Wellington: Departement of Conservation, New Zealand. 
Martinez, C. L. (2003) Evaluation Report: Tools Cluster Networking Meeting \#1. Arizona: Center Point Institute.

Meyliana, Ihandi, Sukanto, dan Eltong Willyanta. (2011). Analisis Kepuasan Mahasiswa terhadap Kinerja LMS BINUSMaya pada Jurusan Sistem Informasi Universitas Bina Nusantara (Studi Kasus Penerapan e-CRM). Skripsi S1 Universitas Bina Nusantara. Skirpsi tidak diterbitkan. Jakarta.

Sugiyono. (2008). Metode Penelitian Bisnis. Bandung: Alfabeta. 